\title{
Dimension Effect on Plate Load Test Results
}

\author{
D. A. M. Araújo' , C. M. L. Costa ${ }^{2}$, Y. D. J. Costa ${ }^{2}$ \\ ${ }^{1}$ Federal University Rural do Semi-Árido \\ Centro de Engenharias, Costa e Silva, 59625-900, Mossoró, RN, Brazil \\ ${ }^{2}$ Federal University of Rio Grande do Norte \\ Campus Universitário Lagoa Nova, 59078-970, Natal, RN, Brazil \\ duilio.marcal@ufersa.edu.br; carina@ct.ufrn.br; ydjcosta@ct.ufrn.br
}

\begin{abstract}
Footing size effect of shallow foundations in sand is investigated in this paper. Three plate load tests were carried out on a sand backfill using plates with diameters of $0.30,0.5$ and $0.80 \mathrm{~m}$. The stress-settlement curves obtained with the tests did not show a clear failure pattern, therefore, conventional failure criteria were used to determinate the bearing capacity. The conventional failure criteria showed different behaviors in respect of the dependence of bearing capacity in relation to the increasing of plate size. For a constant applied stress, settlement increases with increasing plate size. However, settlement values presented a nonlinear behavior with plate size. Housel's three-plate method was used to determinate allowable stresses. The results showed the decrease of the allowable stress as plate dimension increases.
\end{abstract}

Keywords: dimension effect, plate load tests, sand, bearing capacity, settlement

\section{Introduction}

Plate load tests are important field tests for geotechnical engineering practice. In shallow foundation design, the plate load test can be used to determine the stress-settlement relationship, the bearing capacity, and failure modes of shallow foundations. If a plate load tests is used to evaluate settlement and bearing capacity of the foundation, an extrapolation from model to prototype is needed. The model is represented by the plate and the prototype is the actual footing. A few studies have found that bearing capacity increases with increasing plate dimension $[1,2,3]$. However, other studies have found an opposite trend [4,5]. Vianna [1] conducted plate load tests in a saturated sandy soil. It was observed, for plates with diameter between 0.2 and $0.8 \mathrm{~m}$, an increase of the bearing capacity with plate dimension. On the other hand, the bearing capacity reduced as the diameter of the plate increased from $0.8 \mathrm{~m}$ to $1.5 \mathrm{~m}$. Disagreement among previous studies shows the importance of revisiting this subject. This paper presents results of plate load tests with different sizes carried out in a sand deposit. The effect of footing size on bearing capacity, allowable stresses and settlement was evaluated.

\section{Plate Load Tests and Site Conditions}

The plate load tests were carried out in a sand deposit compacted with relative density (Dr) of $45 \%$. Particle size distribution analysis was performed according to Brazilian standard NBR 7181 [6]. Figure 1 presents the particle size distribution of the soil, which shows a predominance of medium sand.

The sand has a maximum void ratio of 0.83 and a minimum void ratio equal to 0.60. Triaxial CID tests showed effective cohesion (c) of $0 \mathrm{kPa}$ and effective friction angle of $32^{\circ}$ [7]. 


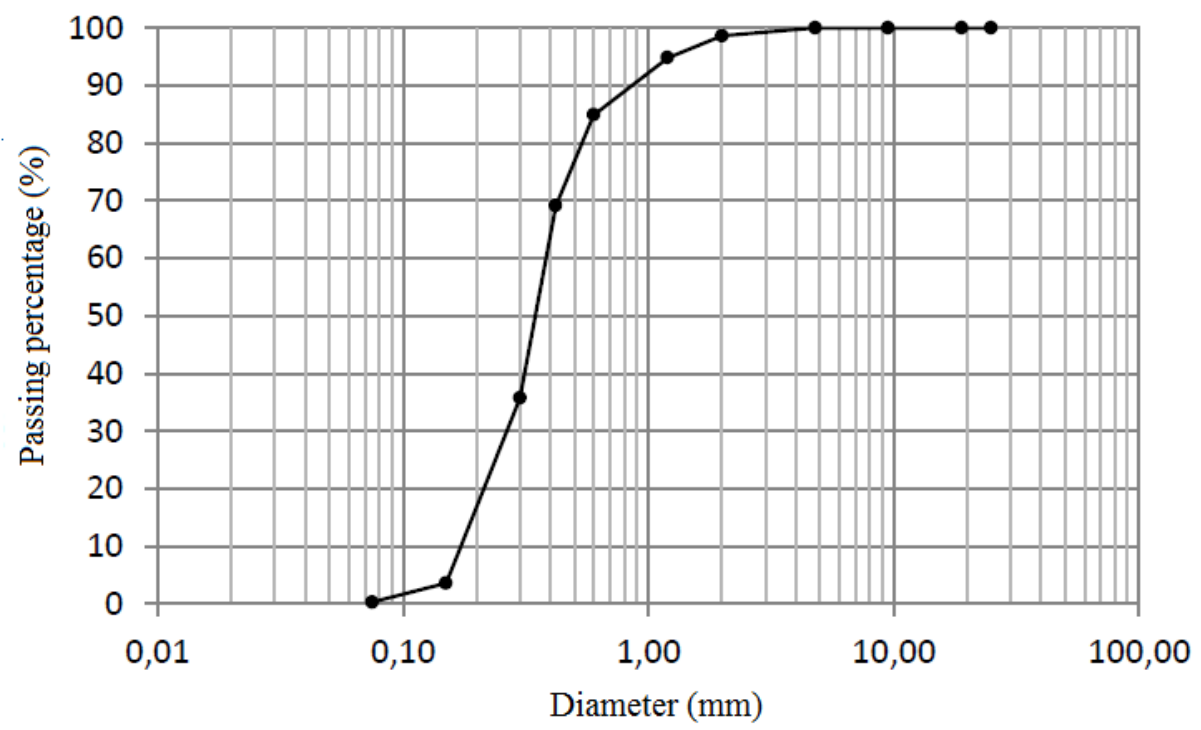

Fig. 1: Gradation curve.

The tests were carried out using circular plates with diameters of $0.3,0.5$ and $0.8 \mathrm{~m}$ laying at a depth of $0.5 \mathrm{~m}$ below ground surface. The plates were made of steel and had thickness of $25 \mathrm{~mm}$. Each plate load test was carried out with quick maintained load (QML), with 15-minute load increments [8]. In each load stage, settlement readings were recorded at 1, 2, 4, 8, and 15 min. Unloading was conducted with four 5-minute decrements. The maximum load in the tests was limited by the reaction system. A truck was used as reaction system with the test with the $0.3 \mathrm{~m}$ plate. The tests with the plates with $\mathrm{D}$ $=0.5$ and $0.8 \mathrm{~m}$ were performed with reaction systems composed by a steel reaction beam fixed on concrete piles. The load was applied with a 500-kN jack, and was measured by a load cell with $500 \mathrm{kN}$ maximum capacity. The settlements of the plate were measured by four mechanical dial gages with a resolution of $0.01 \mathrm{~mm}$.

\section{Footing Size Effect on Settlements}

The stress-settlement curves obtained with the plate load tests are shown in Figure 2. It should be noted that for the same applied stress level, there is an increasing of settlement with the increasing of plate dimension. This behavior was already presented in plate load tests results performed by other researchers, e.g. [1,4,5].

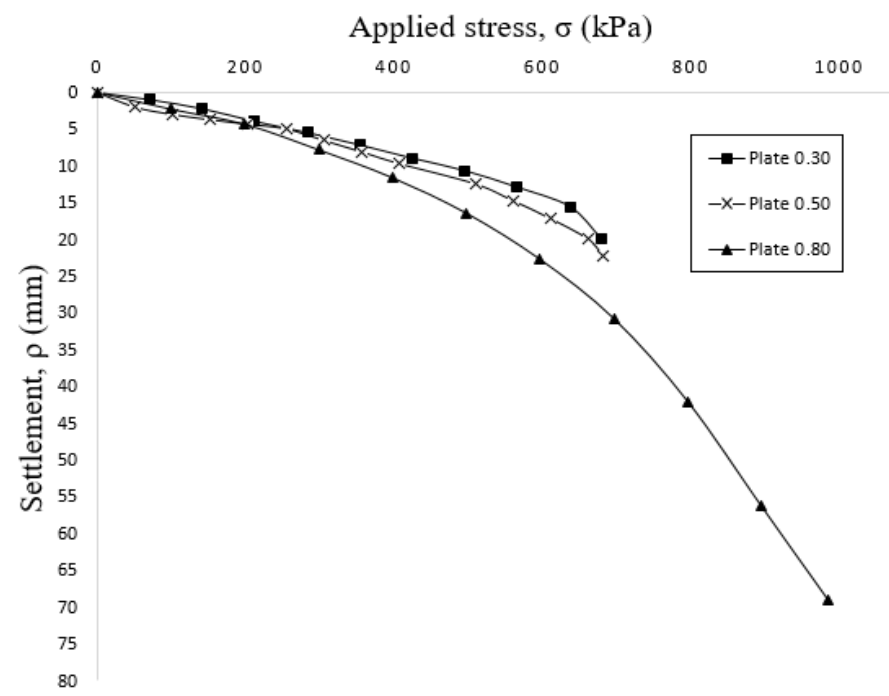

Fig. 2: Stress-settlement curves. 
To evaluate the settlement behavior related to footing size effect, settlement values related to specific applied stresses were considered. Figure 3 presents the settlements obtained for applied stresses of 200, 400 and $600 \mathrm{kPa}$ for different plate dimensions.

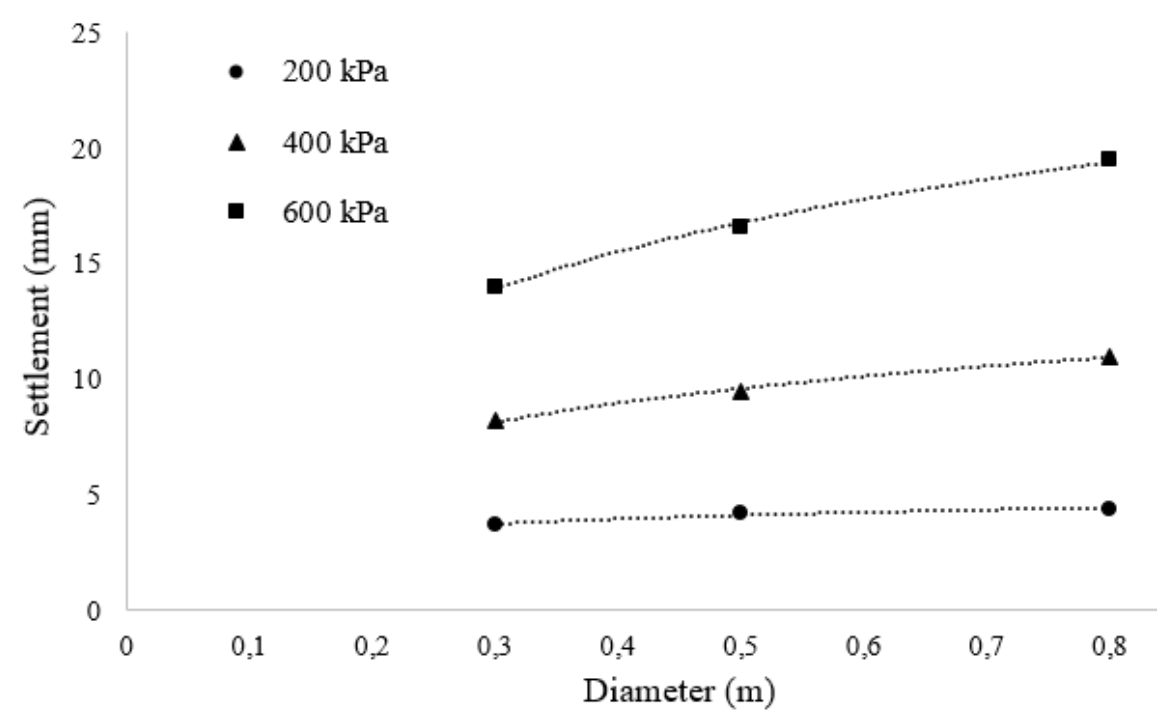

Fig. 3: Settlement versus plate dimension for various stress levels.

Figure 3 shows that settlement increases with increasing plate dimension. The larger the plate size, the larger the deforming soil mass beneath the plate, which results in larger settlements. Nevertheless, an opposite effect is also observed. The increase in plate size generates a deeper stress bulb in the sand mass beneath the plate. The soil mass within the larger bulb is stiffer due to confinement effect, which reduces soil deformation. The combination of both opposite effects results in a nonlinear behavior of plate settlement with increasing plate dimension.

\section{Footing Size Effect on Bearing Capacity}

No clear failure pattern was observed with the stress-settlement curves. All curves showed a hardening behavior, which is a development of greater stress values with increasing settlement. Hence, two conventional failure criteria were considered: the method proposed by Leonards [9] and the criteria that considers the bearing capacity as the stress for a settlement equal to $\mathrm{B} / 30$, where $\mathrm{B}$ is the plate size.

The Leonards' method considers that the bearing capacity is the intersection point between a tangent line at the initial part of the stress-settlement curve and other line at the end part of the curve. The B/30 criterion is related to Brazilian standard for piles [10] adapted for shallow foundations, and frequently used in Brazil. In this case, the failure stress will be that one corresponding to a settlement of $\mathrm{B} / 30$. For comparison, the values of bearing capacity using the Equation 1 proposed by Terzaghi and Peck [11] were also calculated. The bearing capacity factors used were proposed by De Beer [12] and Vesic [13]. The theoretical method proposed by Terzaghi and Peck [11] predicts a linear increase of bearing capacity with increasing footing dimension.

$$
\sigma r=c \cdot N c \cdot S c+q \cdot N q \cdot S q+0 \cdot 5 \cdot \gamma \cdot B \cdot N \gamma \cdot S \gamma
$$

Where: $\sigma \mathrm{r}=$ bearing capacity $[\mathrm{kPa}] ; \mathrm{c}=$ soil cohesion $[\mathrm{kPa}] ; \mathrm{q}=\gamma \cdot \mathrm{h}[\mathrm{kPa}] ; \gamma=$ unit weight of soil $\left[\mathrm{kN} / \mathrm{m}^{3}\right] ; \mathrm{h}=\mathrm{depth}$ of footing embedment $[\mathrm{m}] ; \mathrm{B}=$ footing width $[\mathrm{m}] ; \mathrm{Nc}, \mathrm{Nq}, \mathrm{N} \gamma=$ nondimensional bearing capacity factors; $\mathrm{Sc}, \mathrm{Sq}, \mathrm{S} \gamma=$ nondimensional footing shape factors.

Table 1 presents the values of bearing capacity by both mentioned criteria and also by Equation (1). 
Table 1: Bearing capacity values.

\begin{tabular}{|c|c|c|c|}
\hline Test & $\begin{array}{c}\text { Leonards (1962) } \\
{[\mathbf{k P a}]}\end{array}$ & B/30 [kPa] & $\begin{array}{c}\text { Terzaghi and Peck } \\
\mathbf{( 1 9 6 7 )}[\mathbf{k P a}]\end{array}$ \\
\hline Plate $0.30 \mathrm{~m}$ & 630 & 470 & 392 \\
\hline Plate $0.50 \mathrm{~m}$ & 600 & 580 & 426 \\
\hline Plate $0.80 \mathrm{~m}$ & 570 & 630 & 476 \\
\hline
\end{tabular}

Table 1 shows that the variation of bearing capacity with plate dimension occurs differently with each criterion. For Leonards' method, the stress values decrease with increasing plate dimension, however, with the B/30 method the stress values increase with increasing plate dimension. Leonards' method is a graphic method that takes into account the development of stress-settlement curve. Since the settlement increases with increasing plate dimension the method shows minor failure stress values as plate size increases. This behavior is the opposite of the prediction with Equation (1), since theoretical methods presents a linear increasing of bearing capacity in function of plate size. B/30 criterion has the failure parameter related to dimension of the plate, thus, when the plate diameter increases the settlement value increases as well, reaching larger stress failures. The values obtained by Equation (1) resulted overconservative, especially for plate $0.30 \mathrm{~m}$.

\section{Footing Size Effect on Allowable Stresses}

In order to determine the allowable stress, a safety factor equal to two was adopted for each criteria used in the analysis. The stress value was also limited by a settlement of $10.0 \mathrm{~mm}$. This value of settlement was adopted herein as an allowable settlement.

Other procedure used to determine allowable stress was the method proposed by Housel [14], known as the three-plate method. This procedure creates a linear trend of allowable stress in function of dimension after adopting an allowable settlement.

To use this method at least three plates are needed from load tests with different plate dimensions. After adopting an allowable settlement, it must take the stress values corresponding to allowable settlement in each stress-settlement curve (according to Figure 4a). After that a graph as presented in Figure $4 \mathrm{~b}$ can be drawn. Figure $4 \mathrm{~b}$ shows the obtained stresses form Figure $4 \mathrm{a}$ and the ratio between perimeter $(\mathrm{P})$ and area $(\mathrm{A})$ of the plate. Based on Figure 4b, parameters " $\mathrm{n}$ " e " $\mathrm{m}$ " are determined to use Equation (2). This equation will determine the allowable stress for any required dimension.

$$
\sigma \mathrm{a}=\mathrm{n}+\mathrm{m} .(\mathrm{P} / \mathrm{A})
$$

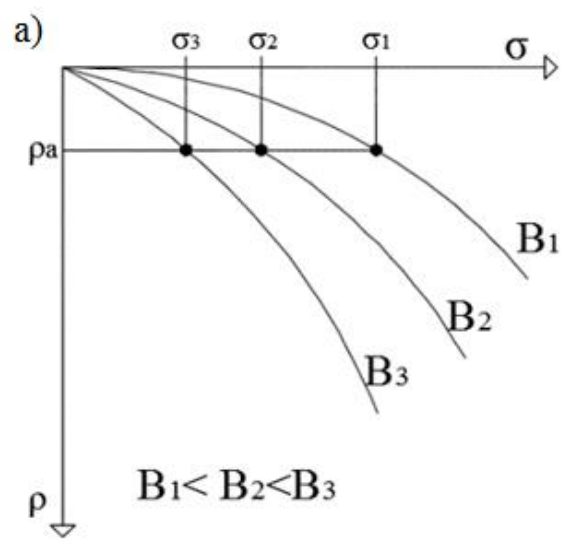

b)

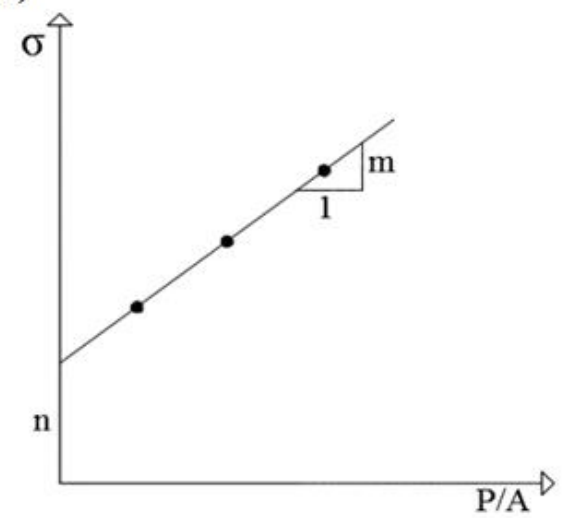

Fig. 4: Housel's three-plate method. 
Table 2 presents allowable stress values for plates with diameters of $0.30,0.50$ and $0.80 \mathrm{~m}$ considering the previous discussed methods.

Table 2: Allowable stress values.

\begin{tabular}{|c|c|c|c|}
\hline Test & $\begin{array}{c}\text { Leonards (1962) } \\
{[\mathbf{k P a}]}\end{array}$ & B/30 [kPa] & Housel [kPa] \\
\hline Plate $0.30 \mathrm{~m}$ & 315 & 235 & 475 \\
\hline Plate $0.50 \mathrm{~m}$ & 300 & 290 & 408 \\
\hline Plate $0.80 \mathrm{~m}$ & 285 & 315 & 370 \\
\hline
\end{tabular}

The values obtained by the methods of Leonards and Housel decreased with increasing plate dimension, however, the allowable stress by Leonards method was more conservative. Another disadvantage of Leonards' method is the subjectivity of the method, once it is a graphic procedure. The three-plate method produces a more complete result because the stress is related to a value of allowable settlement. The result of $\mathrm{B} / 30$ procedure differs from other methods and showed the increasing of the allowable stress with increasing plate dimension.

Figure 5 shows the results of three-plate procedure for different values of allowable settlement. Linear trends of allowable stresses were determined for four allowable settlements, which were: 2.5, 5.0, 10.0 and $25.0 \mathrm{~mm}$. The four linear trends were related to four linear equations, that allow the extrapolation of allowable stress to other plate sizes. Table 3 shows the four linear equations obtained by linear trends of Figure 5, also the allowable stresses extrapolated for plate sizes of $1,2,3$ and $4 \mathrm{~m}$ using the equations shown in Table 3.

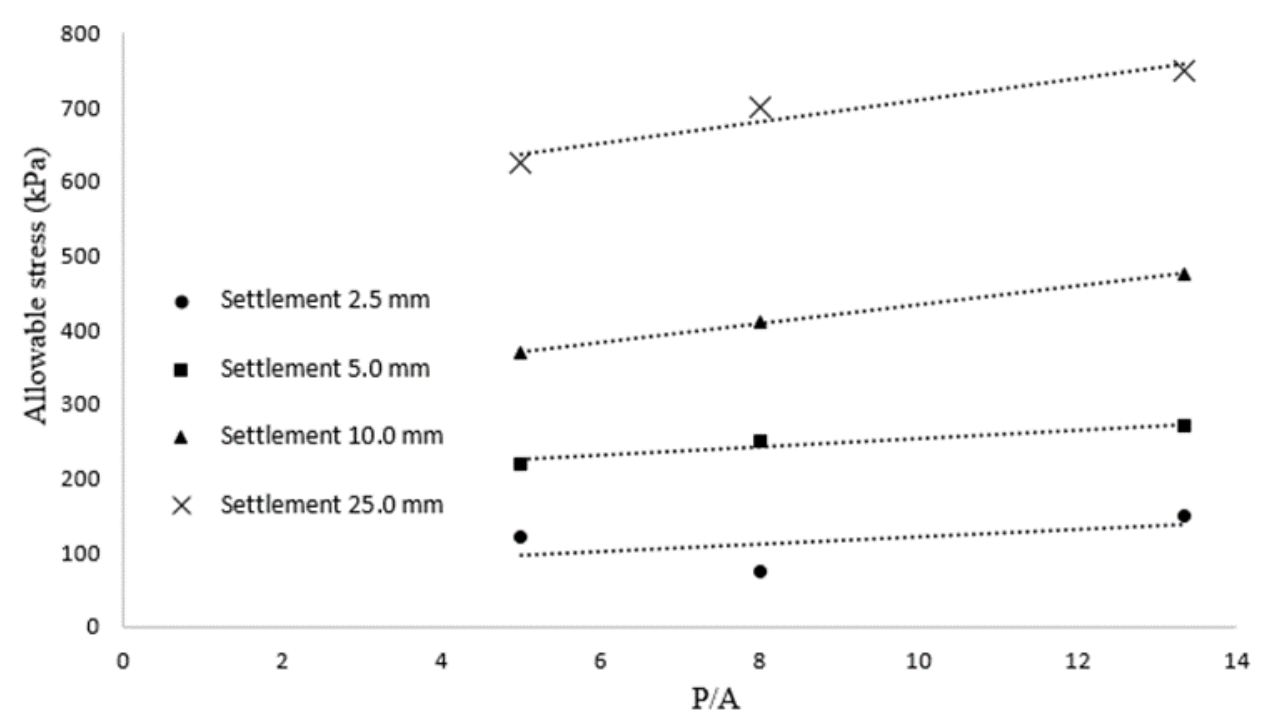

Fig. 5: Three-plates method results.

Table 3: Linear equations and allowable stress values for plates of 1,2,3 and $4 \mathrm{~m}$.

\begin{tabular}{|c|c|c|c|c|c|}
\hline \multirow{2}{*}{$\begin{array}{c}\text { Settlement } \\
(\mathrm{mm})\end{array}$} & \multirow{2}{*}{ Equation } & \multicolumn{4}{|c|}{ Allowable Stress [kPa] } \\
\cline { 3 - 5 } & & $\mathrm{B}=1 \mathrm{~m}$ & $\mathrm{~B}=2 \mathrm{~m}$ & $\mathrm{~B}=3 \mathrm{~m}$ & $\mathrm{~B}=4 \mathrm{~m}$ \\
\hline 2.5 & $\mathrm{qa}=72.70+4.8 \times(\mathrm{P} / \mathrm{A})$ & 91.90 & 82.30 & 79.10 & 77.50 \\
\hline 5.0 & $\mathrm{qa}=196,3+5.75 \times(\mathrm{P} / \mathrm{A})$ & 219.30 & 207.80 & 203.97 & 202.05 \\
\hline 10.0 & $\mathrm{qa}=308.15+12.5 \times(\mathrm{P} / \mathrm{A})$ & 358.15 & 333.15 & 324.82 & 320.65 \\
\hline 25.0 & $\mathrm{qa}=565+14.35 \times(\mathrm{P} / \mathrm{A})$ & 622.40 & 593.70 & 584.13 & 579.35 \\
\hline
\end{tabular}

The values presented in Table 3 show that the increase in plate dimension causes a decreasing of allowable stress. This behavior is expected once the settlement value is limited, thus an increasing plate dimension causes an increasing 
settlement. Therefore, for foundation designs in which settlement is as important as bearing capacity, this type of procedure must be considered, once the results easily combine stress and settlement.

\section{Conclusion}

Plate load tests were conducted in sand using different plate diameters. The field tests allowed evaluating bearing capacity, settlements and allowable stresses considering the effect of plate size on the test results. None stress-settlement curves presented clear failure, thus, failure criteria were adopted to define bearing capacity. Regarding this study, the following conclusions can be drawn:

- Load test results showed that for a same applied stress the settlement values increases as the plate dimensions increases as well, but this increasing is nonlinear.

- Each failure criterion presented distinct response in respect to the behavior of bearing capacity depending on plate dimension. Leonards criterion showed a decreasing of bearing capacity with the increasing of plate dimension, while the $\mathrm{B} / 30$ procedure presented opposite behavior. This behavior shows the dependency of failure criteria on the results. The difference of response among methods also may be the cause of some authors determinate increasing of bearing capacity with increasing plate dimension and other authors the opposite. Bearing capacity values obtained by the theoretical equation (Terzaghi and Peck's equation) were too conservative.

- The values of allowable stress obtained by the three-plate method of Housel [15] decreased with the increasing of plate size. The same was observed for Leonards' criterion. This behavior is consistent because a value of allowable settlement was adopted and the settlement values increase as plate size increases, regarding the same applied stress. Shallow foundation on sand, generally, present high failure stress values, thus, the stresses used are frequently limited by the required settlement. Therefore, for foundation design the three-plate method is an important alternative once that combines stress and settlement.

\section{References}

[1] A. P. F. Vianna, "Size and matric suction influence in the behavior of shallow foundations in unsaturated sandy soils," Ph.D. thesis, Escola de Engenharia de São Carlos, Universidade de São Paulo, São Carlos/SP, 2005. (In Portuguese)

[2] A. B. Cerato and A. J. Lutenegger. "Scale effects of shallow foundation bearing capacity on granular soils," Journal of Geotechnical and Geoenvironmental Engineering, ASCE, vol. 133, pp. 1192-1202, 2007.

[3] N. C. Consoli, F. D. Rosa, A. Fonini, "Plate load tests on cemented soil layers overlaying weaker soil," Journal of Geotechnical and Geoenvironmental Engineering, ASCE, vol. 135, pp. 1846-1856, 2009.

[4] J. Briaud and P. Jeajean. "Load settlement curve method for spread footings on sand," In SETTLEMENT '94 SPECIALITY CONFERENCE, ASCE, Special Publication, no. 40, pp. 1774-1804, 1994.

[5] R. Cudmani, "Study of footing settled on residual soil parcial-saturated behavior by plate load test," M.S. dissertation, UFRGS, Porto Alegre/RS, 1994. (In Portuguese)

[6] ABNT - NBR 7181 - Granulometric Analysis, Rio de Janeiro, 1984. (In Portuguese)

[7] A. G. D. Araújo. "Static lateral loading tests on CFA bored piles and metalic driven piles in cohesionless soil," M.S, dissertation, PEC, UFRN, Natal/RN, 2013. (In Portuguese)

[8] B. H. Fellenius. "The load of piles and new proof testing procedure," Journal of the Geotechnical Engineering Division, ASCE, vol. 101, no. 9, pp. 855-869, 1975.

[9] G. A. Leonards. Footing Engineering, Mc Graw, Hill Ed, 1962.

[10] ABNT - NBR 6122, Design and execution of foundation. Rio de Janeiro, 2010. (In Portuguese)

[11] K. Terzaghi and R. B. Peck, Soil mechanics in engineering practice. John Wiley and Sons, New York, 1967.

[12] E. E. De Beer. Proefondervindelijke bijdrage tot de studie van het grensdraag vermogen van zand onder funderingen op staal. Tijdshrift der Openbar Werken van Beigie Nos, 1967.

[13] A. S. Vesic. "Bearing capacity of shallow foundations," In WINTERKORN, H. F. e FANG, H.Y. Foundation Engineering Handbook, New York. cap. 3, pp, 121-147, 1975.

[14] W. S. Housel. A practical method for the selection of foundations based on fundamental research in soil mechanics. Research Bulletin, N 13, University of Michigan, Ann Arbour, 1929. 